\title{
Dairy manure biochar modified with sodium hydroxide and its effect on lead removal in aqueous solution
}

\author{
Zhihui Yuan ${ }^{1, a}$, Minchao Liu, ${ }^{1, b}$, Zhiliang Chen ${ }^{2, c}$ \\ ${ }^{1}$ School of Chemical and Environmental Engineering, Wuyi University, Jiangmen, Guangdong, \\ 529020, China \\ ${ }^{2}$ South China Institute of Environment Sciences, Ministry of Environmental Protection, Luogang, \\ Ruihe Road 18, Guangzhou, Guangdong, 530000, China \\ azzcaptain@163.com, bwyuchemlmc@126.com, chenzhiliang@scies.org
}

\begin{abstract}
Keywords: Dairy manure; Biochar; Modified; Lead; Sorption.
Abstract. This work explored one effective modification method to improve dairy manure biochar's ability to sorb lead. Dairy manure pyrolyzed at $300^{\circ} \mathrm{C}$ for $4 \mathrm{~h}$ was dispersed into liquor sodium hydroxide to get sorption ability improved. The resulting biochar(NB300) was used for batch sorption studies to determine the kinetics and magnitude of $\mathrm{Pb}^{2+}$ sorbed onto the modified biochar. The max $\mathrm{Pb}^{2+}$ sorption capacity of NB300(192.2 $\left.\mathrm{g} \mathrm{kg}^{-1}\right)$ was significantly higher than that of the unmodified biochar.
\end{abstract}

\section{Introduction}

Reclamination of heavy metal ions via sorption is a prevailing and convenient approach to remove heavy metals, such as lead $\left(\mathrm{Pb}^{2+}\right)$ from waster water[1]. Recently, researches have focused on producing more environmentally friendly and cost efficient sorbent materials that have similar characteristics with activated carbon[2]. Biochar has been considered as a kind of strong sorbent for $\mathrm{Pb}^{2+}[3]$. However, the lead sorption capacity of most of the original biochar was lower than some commercial or modified sorbents[4]. Thus, this research aimed at increasing sorption capacity of biochar.

Dairy manure pyrolytic under lower temperature for example $200^{\circ} \mathrm{C}$ has gained a relatively high sorption capacity of $93.6 \mathrm{~g} \mathrm{~kg}^{-1}$ for $\mathrm{Pb}^{2+}[5]$, which was 6 times more effective in $\mathrm{Pb}^{2+}$ sorption than commercial activated carbon. The fundamental purpose of this work was to introduce a new way to enhance the sorption capacity of dairy manure biochar for $\mathrm{Pb}^{2+}$.

\section{Methods}

\section{Reagents}

Sodium hydroxide $(\mathrm{NaOH})$, lead nitrate $\left(\mathrm{Pb}\left(\mathrm{NO}_{3}\right)_{2}\right)$, hydrochloric acid $(\mathrm{HCl})$ of superior grade were bought from Fisher Scientific. Deionized (DI) water was applied in each experiment(Nanopure water, Barnstead). Dairy manure was provided by GuangZhou China Grand Biotechnology Co., Ltd, in the summer of 2015.

\section{Sorbent preparation}

Modified dairy manure biochar(NB300)

Firstly, dairy manure was dried out, pulverized and passed through $2 \mathrm{~mm}$ sieve. Then the grinded dairy manure was heat-treated under oxygen-limited condition at $300^{\circ} \mathrm{C}$ for $4 \mathrm{~h}$, with a heating rate of $5^{\circ} \mathrm{C} \mathrm{min}^{-1}$. The cooling product was mixed with $2 \mathrm{~mol} \mathrm{~L}^{-1}$ sodium hydroxide $(\mathrm{NaOH})$ at radio of 1 : $3(\mathrm{~W} / \mathrm{V})$ in a $1000 \mathrm{~mL}$ polyethylene plastic bottle and heated to $60^{\circ} \mathrm{C}$ at a fully automatic flip type oscillator with a turnover rate of $30 \mathrm{rpm}$ for $12 \mathrm{~h}$. The finally solid product was washed several times with distilled water and dried at $105^{\circ} \mathrm{C}$ overnight. The modified dairy manure biochar obtained at this stage was used in this study and defined as NB300. 


\section{Sorbent characterization}

Total carbon $(\mathrm{C})$, hydrogen $(\mathrm{H})$, nitrogen $(\mathrm{N})$, and oxygen $(\mathrm{O})$ contents in the NB300 were analyzed with $\mathrm{CHON}$ elemental analyzer(MicaoCube, Elementar, Germany). Total surface area was measured using $\mathrm{N}_{2}$ sorption Brunauer Emmet Teller method on a NOVA 1200 analyzer.

\section{Adsorption equilibrium}

Investigation of $\mathrm{Pb}^{2+}\left(300 \mathrm{mg} \mathrm{L}^{-1}\right)$ sorption kinetic was conducted in $50 \mathrm{~mL}$ polypropylene tubes by mixing $0.03 \mathrm{~g}$ of material with $20 \mathrm{~mL}$ of heavy metal ion solution in which $0.01 \mathrm{M} \mathrm{NaNO}_{3}$ solution was served as background electrolyte. The tubes were placed on a reciprocating shaker at $180 \mathrm{rpm}$ until further filtration process. At each sampling time $(0,0.25,0.5,1,2,4,8,12$, and $24 \mathrm{~h})$, the mixed liquor was immediately filtered through $0.45 \mu \mathrm{m}$ microporous filter. $\mathrm{Pb}^{2+}$ in the filtrate was measured(AAS-7000, Shimadzu, Japan) and the adsorption quantity was calculated as the difference between initial and final solution concentrations of the sorbate. Adsorption isotherm was determined for $\mathrm{Pb}^{2+}$ using the same method just as mentioned above but using a scope of $\mathrm{Pb}^{2+}(20 \mathrm{~mL}, 20 \sim 800$ $\mathrm{mg} \mathrm{mL}^{-1}$ ) sorbent solution concentrations for $12 \mathrm{~h}$ contact period. Three replicates were conducted for each treatment. Each solution $\mathrm{pH}$ was adjusted to 5.5.

\section{Results and discussion}

\section{Sorbent properties}

The $\mathrm{pH}$, ash content, element analysis were shown in Table 1. In addition to ash and nitrogen contents, the $\mathrm{pH}$ and element percentage increased after chemical modification. The contents of oxygen containing functional groups were generally improved, the lactonic groups were no detected.

Table 1 Selected physicochemical properties of NB300.

\begin{tabular}{ccccccccccc}
\hline Material & $\mathrm{pH}$ & $\mathrm{C}(\%)$ & $\mathrm{H}(\%)$ & $\mathrm{O}(\%)$ & $\mathrm{P}(\%)$ & $\mathrm{BET}^{d}$ & $\mathrm{Ash}(\%)$ & $\begin{array}{c}\text { Carboxylic } \\
\text { groups }\end{array}$ & $\begin{array}{c}\text { Phenolic } \\
\text { hydroxyl } \\
\text { groups }\end{array}$ & $\begin{array}{c}\text { Lactonic } \\
\text { groups }\end{array}$ \\
\hline $\mathrm{NB} 300$ & 9.98 & 12.07 & 1.79 & 11.15 & 2.9 & 25.94 & 27.13 & 0.5973 & 0.1073 & n.d $^{f}$ \\
\hline${ }^{d}$
\end{tabular}

${ }^{d}$ Surface area $\left(\mathrm{m}^{2} \mathrm{~g}^{-1}\right) ;{ }^{e}$ unit: $\mathrm{mmol} \mathrm{g}{ }^{-1} ;{ }^{f}$ no-detected.

\section{Pb2+ sorption kinetic and isotherm}

$\mathrm{Pb}^{2+}$ sorption by NB300 showed biphasic, with a phase of rapid growth during a few of first hours before a much slow sorption stage(Fig. 1). The rapid sorption stage maybe attribute to the rapid occupation of easily accessible external surface sorption sites, likely via physical sorption[6]. For example, rapid sorption kinetics were reported for $\mathrm{Pb}^{2+}$ sorption by two biochar materials prepared by pyrolysis dairy manure under low temperature of $200^{\circ} \mathrm{C}$ and $350^{\circ} \mathrm{C}$, the same observation presented for the sorption of $\mathrm{Pb}^{2+}$ by biochar-derived from chicken manure and green waste[7]. The sorption kinetic dates were fitted with pseudo-first-order, pseudo-second order, and Elovich kinetic models to provide insight into the potential sorption mechanism. $\mathrm{Pb}^{2+}$ sorption by NB300 was best-fitted by the pseudo-second order model with $\mathrm{R}^{2}>0.99$. Based on the results of pseudo-second order model, the initial adsorption rates of $\mathrm{Pb}^{2+}$ were much larger than that of BC200[5]. Sorption capacity of NB300 for $\mathrm{Pb}^{2+}$ over the first half hour can reach $158.8 \mathrm{~g} \mathrm{~kg}^{-1}$ which was much higher to the maximum adsorption capacity of $93.6 \mathrm{~g} \mathrm{~kg}^{-1}$ by BC200.

The sorption isotherm was conducted by varying the ratio of sorbate to sorbent and was shown in Fig. 2. At low sorbate concentrations, sorption isotherm increased rapidly with increasing equilibrium sorbate concentrations. Sorption ability slowed down at higher sorbate concentrations. Langmuir model fitted the $\mathrm{Pb}^{2+}$ sorption isotherm dates well $\left(\mathrm{R}^{2}>0.99\right)$. The Langmuir maximum sorption capacity of NB300 for $\mathrm{Pb}^{2+}$ was about 2 times as greater as that of $\mathrm{BC} 200$ [5]. These results confirmed that the modification enhanced the $\mathrm{Pb}^{2+}$ sorption ability of the diary manure biochar. The maximum 
$\mathrm{Pb}^{2+}$ sorption ability of the modified biochar is comparable to the most of other adsorb materials derived from waste biomass reported in the literature, which was showed in Table 2.

Table 2 Sorption capacities for $\mathrm{Pb}^{2+}$ onto NB300 and various sorbents.

\begin{tabular}{ll}
\hline Material & $\mathrm{Pb}^{2+}$ sorption capacity $\left(\mathrm{g} \mathrm{kg}^{-1}\right)$ \\
\hline NB300 & 192.22 \\
Pretreatment of Kaolinite clay with tripolyphosphate[8] & 126.58 \\
Chicken manure-derived biochar (CM)[7] & 11 \\
$\mathrm{Fe}_{2} \mathrm{O}_{3} /$ oak bark biochar[9] & 30.2 \\
Anaerobically digested sugarcane bagasse[10] & 131.63 \\
Alternanthera philoxeroides biochar(APB)[11] & 257.12 \\
\hline
\end{tabular}

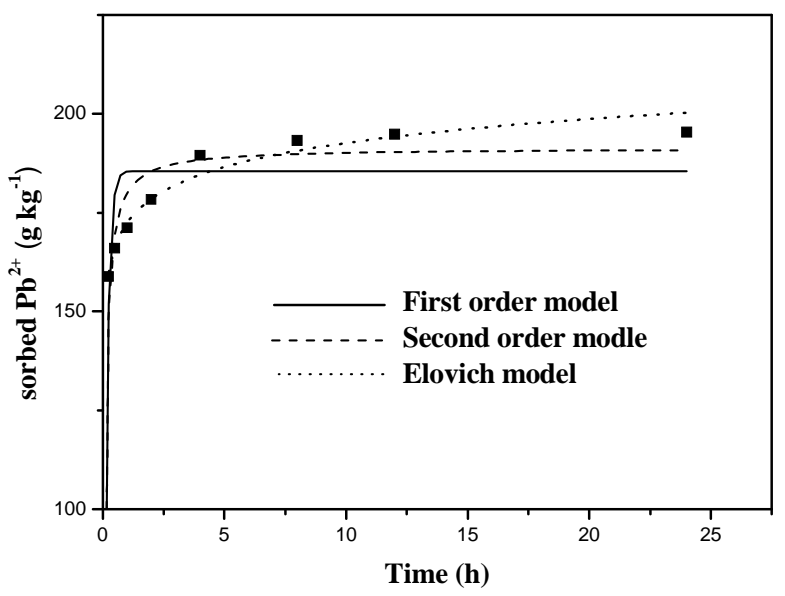

Fig. 1. $\mathrm{Pb}^{2+}$ sorption kinetic dates and fitted models for NB300.

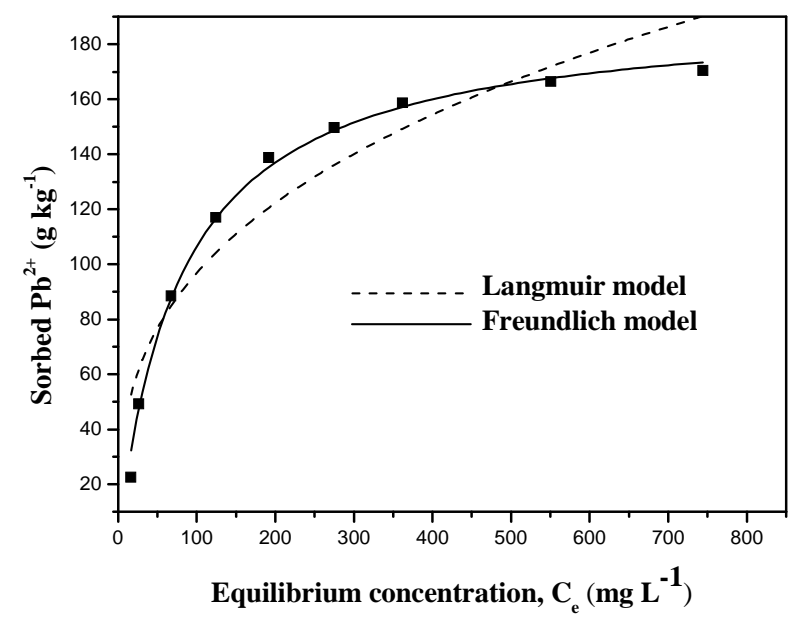

Fig. 2. $\mathrm{Pb}^{2+}$ sorption isotherm dates and fitted models for NB300.

\section{Sorption mechanisms}

Generally, surface chemistry, surface area of the sorbent, precipitation reactions always govern sorption of heavy metals in aqueous solutions[12]. The surface area of NB300 was $25.94 \mathrm{~m}^{2} \mathrm{~g}^{-1}$. This message revealed that sorption of $\mathrm{Pb}^{2+}$ by NB300 was likely governed by surface area, as was reported in a previous study that sorption of $\mathrm{Pb}^{2+}$ was attributed to adsorption-precipitation mechanism. Previous studies have suggested that additional of $\mathrm{P}$ induces formation of insoluble $\mathrm{Pb}$-phosphate minerals in Pb-contaminated water and soils[13]. Elemental analysis showed that NB300 was rich in 
$\mathrm{P}(2.9 \%)$. Thus, the slow adsorption stage of $\mathrm{Pb}^{2+}$ removal by NB300 may be attributed to the formation of $\mathrm{Pb}$-phosphate precipitate. The $\mathrm{Pb}-\mathrm{P}$ precipitation can be described as Eq. 1[5]:

$$
6 \mathrm{HPO}_{4}^{2-}+9 \mathrm{~Pb}^{2+}+6 \mathrm{OH}^{-} \rightarrow \mathrm{Pb}_{9}\left(\mathrm{PO}_{4}\right)_{6}+6 \mathrm{H}_{2} \mathrm{O}
$$

Dairy manure biochar mixed with sodium hydroxide may generate new hydroxyl minerals, lead the internal carbonate burst out into the adsorption site, which facilitate the precipitation formation, like the hydrocerussite $\mathrm{Pb}_{3}\left(\mathrm{CO}_{3}\right)_{2}(\mathrm{OH})_{2}$. The precipitation of $\mathrm{Pb}^{2+}$ with carbonate mineral can be described as Eq. 2[5]:

$$
2 \mathrm{HCO}_{3}^{-}+3 \mathrm{~Pb}^{2+}+4 \mathrm{OH}^{-} \rightarrow \mathrm{Pb}_{3}\left(\mathrm{CO}_{3}\right)_{2}(\mathrm{OH})_{2}+2 \mathrm{H}_{2} \mathrm{O}
$$

\section{Conclusions}

This study indicated that chemical modification of dairy manure biochar can effectively increase $\mathrm{Pb}^{2+}$ removal ability from aqueous solutions. The $\mathrm{Pb}^{2+}$ sorption capacity by NB300 demonstrated in this study was comparable to most of the materials' derived form waste biomass. Thus, NB300 converted from $\mathrm{NaOH}$ post-processing can be used as an alternative sorbent for activated carbon or other water purifiers to treat heavy metals in wastewater.

\section{Acknowledgements}

This work was financially supported by the Cooperation Plan of Industry, Education, Academy Sponsored by Guangdong province government, Education Department/Science and Technical Department of Chinese government (2012B091000152), and the science and technology project of Guangdong, China (2013B020700010).

\section{References}

[1] Lu, H.; Zhang, W.; Yang, Y.; Huang, X.; Wang, S.; Qiu, R. Water research 2012, 46 (3), 854-862.

[2] Inyang, M.; Gao, B.; Pullammanappallil, P.; Ding, W.; Zimmerman, A. R. Bioresource Technology 2010, $101(22), 8868-8872$.

[3] Inyang, M.; Gao, B.; Yao, Y.; Xue, Y.; Zimmerman, A. R.; Pullammanappallil, P.; Cao, X. Bioresource Technology 2012, 110, 50-56;

[4] Zhou, Y.; Gao, B.; Zimmerman, A. R.; Chen, H.; Zhang, M.; Cao, X. Bioresource technology 2014, 152, 538-542.

[5] Cao, X.; Ma, L.; Gao, B.; Harris, W. Environmental Science \& Technology 2009, 43 (9), 3285-3291.

[6] Mohan, D.; Sarswat, A.; Ok, Y. S.; Pittman, C. U. Bioresource technology 2014, 160, 191-202.

[7] Park, J. H.; Choppala, G.; Lee, S. J.; Bolan, N.; Chung, J. W.; Edraki, M. Water, Air, \& Soil Pollution 2013, 224 (12), 1-12.

[8] Unuabonah, E.; Olu-Owolabi, B.; Adebowale, K.; Ofomaja, A. Colloids and Surfaces A: Physicochemical and Engineering Aspects 2007, 292 (2), 202-211.

[9] Mohan, D.; Kumar, H.; Sarswat, A.; Alexandre-Franco, M.; Pittman, C. U. Chemical Engineering Journal 2014, 236, 513-528.

[10] Inyang, M.; Gao, B.; Ding, W.; Pullammanappallil, P.; Zimmerman, A. R.; Cao, X. Separation Science and Technology 2011, 46 (12), 1950-1956.

[11] Yang, Y.; Wei, Z.; Zhang, X.; Chen, X.; Yue, D.; Yin, Q.; Xiao, L.; Yang, L. Bioresource technology 2014, 171, 227-232.

[12] Echeverria, J.; Morera, M.; Mazkiaran, C.; Garrido, J. Environmental Pollution 1998, 101 (2), 275-284.

[13] Cao, X.; Ma, L. Q.; Chen, M.; Singh, S. P.; Harris, W. G. Environmental Science \& Technology 2002, 36 (24), 5296-5304. 